ISLAMIC BANKING: Jurnal Pemikiran dan Pengembangan Perbankan Syariah, Volume 6 Nomor 1 Edisi Agustus 2020

\title{
HAK WIRAUSAHA PEREMPUAN PERSPEKTIF MAQASID SYARIAH
}

\author{
Ahmad Mukri Aji \\ Fakultas Syariah dan Hukum, Universitas Syarif Hidayatullah, Jakarta \\ Email: mukri.aji@uinjkt.ac.id \\ Harisah \\ Institut Agama Islam Negeri, Madura \\ Email: harisah@iainmadura.ac.id \\ Syarifah Gustiawati Mukri \\ Universitas Ibnu Khaldun Bogor \\ Email: liefah83@gmail.com
}

\begin{abstract}
In today's modern era, it is not uncommon for women to be able to earn income by doing entrepreneurship, both traditional and modern with various perspectives. Entrepreneurial women are sometimes used to channel their hobbies, as well as being the backbone of the family to meet the needs of family life. So that the current rights of women entrepreneurs can be studied with the maqasid sharia approach. From this, researchers are interested in examining the rights of women entrepreneurs with a Sharia perspective. This study was conducted using a qualitative approach with literature data that was analyzed inductively and deductively. This study found that according to maqasid sharia women have rights in entrepreneurship, including the right to channel hobbies, which in the concept of maqasid sharia are included in the category of hifdzul aqli, the second right to earn income in the maqasid sharia concept is called hifdzul nafs.
\end{abstract}

Keywords: Entrepreneur, Woman, Maqasid Sharia

\begin{abstract}
Abstrak
Era modern saat ini, tidak jarang perempuan mampu mencari pendapatan dengan berwirausaha, baik dengan cara tradisional maupun modern dengan berbagai perspektif. Perempuan berwirausaha adakalanya untuk penyaluran hobi, ada juga sebagai tulang punggung keluarga untuk memenuhi kebutuhan hidup keluarga. Sehingga hak wirausaha perempuan saat ini, bisa dikaji dengan pendekatan maqasid syariah. Dari hal tersebut peneliti tertarik untuk mengkaji hak wirausaha perempuan perspektif Syariah. Kajian ini dilakukan dengan menggunakan pendekatan kualitatif dengan sajian data-data kepustakaan yang dianalisa secara induktif dan deduktif. Kajian ini menemukan bahwa menurut maqasid syariah perempuan memiliki hak-hak dalam wirausaha, antara lain hak menyalurkan hobi, yang dalam konsep maqasid syariah
\end{abstract}




\section{2 | Ahmad Mukri Aji, Harisah, Syarifah Gustiawan Mukri, HAK WIRAUSAHA PEREMPUAN..............}

termasuk dalam kategori hifdzul aqli, yang kedua hak untuk mendapatkan penghasilan dalam konsep maqasid syariah disebut sebagai hifdzul nafs.

Kata Kunci: Wirausaha, Perempuan, Maqasid Syariah

\section{Dasar Pemikiran}

Perempuan merupakan bagian dari sebuah masyarakat, karena dia menjadi patner laki-laki dalam memakmurkan bumi dan merealisasikan sebuah pemberdayaan. Ajaran Islam memberikan perhatian yang sangat besar serta kedudukan terhormat kepada perempuan. Muhammad al-ghazali, salah seorang ulama besar Islam kontemporer menyatakan bahwa "kalau kita mengembalikan pandangan ke masa sebelum seribu tahun, maka kita akan menemukan perempuan yang menikmati keistimewaan dalam bidang materi dan sosial yang tidak dikenal oleh perempuan-perempuan dikelima benua. Keadaan mereka ketika itu lebih baik, dibandingkan dengan keadaan perempuanperempuan barat dewasa ini, asal saja kebebasan dalam berpakaian serta pergaulan tidak dijadikan bahan perbandingan".

Al-quran berbicara tentang perempuan dalam berbagai surat, dan pembicaraan tersebut menyangkut berbagai sisi kehidupan. Ada yang berbicara tentang hak dan kewajiban, adapula yang menguraikan keistimewaan tokoh-tokoh perempuan dalam sejarah agama dan kemanusiaan. Seperti dalam surat an-nisa': 32 secara umum menunjukkan hak-hak perempuan: “(karena) bagi laki-laki dianugerahkan hak (bagian) dari apa yang diusahakannya, dan bagi perempuan dianugerahkan hak (bagian) dari apa yang diusahakannya".

Perempuan memiliki hak yang sama dengan laki-laki dalam mengembangkan usaha. Namun, hak perempuan tersebut harus diimbangi dengan kemampuannya dalam menjaga agama. Kalau kita kembali menelaah, keterlibatan perempuan dalam pekerjaan pada masa awal Islam, sangatlah banyak. Hal ini bisa kita lihat dari kenyataan sejarah bahwa perempuan pada masa nabi Muhammad saw aktif dalam berbagai bidang pekerjaan. Seperti Ummu Salim Binti Malhan yang bekerja sebagai perias pengantin, istri pertama nabi yakni Khadijah Binti Khuwailid tercatat sebagai seorang perempuan yang sangat sukses dalam bidang perdagangan, demikian juga Qilat Ummi Bani Anmar yang tercatat sebagai seorang perempuan yang pernah datang kepada nabi untuk 
meminta petunjuk dalam bidang jual beli. Zainab Binti Jahsy (istri nabi saw) juga aktif bekerja menyamak kulit binatang dan hasil usahanya itu beliau sedekahkan. Selain itu ada juga istri sahabat nabi (Abdullah Bin Mas'ud) yang sangat aktif bekerja karena suami dan anaknya ketika itu tidak mampu mencukupi kebutuhan hidup keluarga.(M. Quraish Shihab, 1998, pp. 275-276).

Dalam menjalankan usaha sebagai wirausaha perempuan, mereka memiliki hak dan kewajiban yang harus dijalankan sesuai ajaran syariah. Dengan latar belakang ini, peneliti ingin mengkaji hak-hak perempuan dalam wirausaha perspektif maqashid syariah.

\section{Metode penelitian}

Penelitian ini menggunakan metode penelitian kualitatif dengan jenis kepustakaan, untuk menghasilkan data yang valid sesuai dengan kandungan penelitian. Penggunaan kepustakaan karena penelitian ini menganalisa tentang hak-hak perempuan dalam wirausaha, yang melibatkan nash alquran, hadits, dan pemikiran ulama serta perdebatan ulama modern tentang perempuan yang bekerja, dengan analisa utama menggunakan konsep maqashid syariah. Hal ini dilakukan untuk mendapatkan hasil mendalam mengenai topik penelitian ini.

\section{Hak Perempuan Dalam Pandangan Maqashid Syariah}

Dalam pandangan Islam perempuan memiliki banyak hak, yang didapatkan sebagai bentuk keagungan kedudukan perempuan dalam Islam. Antara lain; Pertama, hak perempuan dalam bidang politik. Dalam hal ini ulama berbeda pendapat tentang boleh tidaknya seorang perempuan terlibat dalam bidang politik. Bagi yang tidak membolehkannya, paling tidak ada tiga alasan yang sering dikemukakannya: alasan pertama, ayat yang berbunyi "ar-rijal qawwamuna 'alan-nisa' (lelaki adalah pemimpin bagi kaum wanita) QS. Al-nisa' : 34. Alasan kedua, hadits yang menyatakan bahwa akal wanita kurang cerdas dibandingkan dengan akal lelaki; keberagamaannya pun demikian. Alasan ketiga, hadits yang mengatakan "lan yaflaha qaum wallauw amrahum imraatan" 


\section{4 | Ahmad Mukri Aji, Harisah, Syarifah Gustiawan Mukri, HAK WIRAUSAHA PEREMPUAN..............}

(tidak akan berbahagia satu kaum yang menyerahkan urusan mereka kepada perempuan).(M.Quraish Shihab, 1998, p. 313)

Menurut M. Quraish Shihab kata "ar-rijal" dalam ayat ar-rijalu qawwamuna 'alan nisa' bukan berarti lelaki secara umum, tetapi adalah "suami" karena konsiderans perintah tersebut seperti ditegaskan pada lanjutan ayat adalah karena "mereka (para suami) menafkahkan sebagian harta untuk isteri-isteri mereka”. Seandainya yang dimaksud dengan kata "lelaki" adalah kaum pria secara umum, tentu konsideransnya tidak demikian. Terlebih lagi lanjutan ayat tersebut secara jelas berbicara tentang para isteri dan kehidupan rumah tangga. Adapun mengenai hadits "tidak beruntung satu kaum yang menyerahkan urusan mereka kepada perempuan"perlu digaris bawahi bahwa hadits tersebut tidak bersifat umum.(M.Quraish Shihab, 1998, p. 314)

Adapun alasan ulama yang membolehkan perempuan terlibat dalam politik yaitu surat at-taubah: 71 “dan orang-orang yang beriman, lelaki dan perempuan, sebagian mereka adalah awliya' bagi sebagian yang lain. Mereka menyuruh untuk mengerjakan yang ma'ruf, mencegah yang munkar, mendirikan shalat, menunaikan zakat, dan mereka taat kepada allah dan rasulnya. Mereka itu akan diberi rahmat oleh Allah. Sesungguhnya Allah maha perkasa lagi maha bijaksana”. Pengertian kata " awliya' “ dalam ayat ini mencakup kerja sama, bantuan dan penguasaan. Sedangkan pengertian yang terkandung dalam frase "menyuruh mengerjakan yang makruf" mencakup segala segi kebaikan dan perbaikan kehidupan, termasuk memberikan nasihat atau kritik kepada penguasa, sehingga setiap lelaki dan perempuan muslim hendaknya mengikuti perkembangan masyarakat agar masing-masing mampu melihat dan memberi saran atau nasihat untuk berbagai bidang kehidupan.(M.Quraish Shihab, 1998, p. 315)

Dari penjelasan diatas dapat disimpulkan bahwa perempuan juga mempunyai hak dalam hal politik, karena ayat maupun hadits yang dijadikan alasan oleh sebagian orang itu bersifat umum. Artinya ketentuan tersebut tidak terbatas hanya pada kaum laki-laki, karena baik laki-laki maupun perempuan sama-sama dibolehkan untuk terlibat didalamnya. Kenyataan sejarah juga menunjukkan bahwa pada masa Rasulullah saw banyak wanita yang terlibat pada persoalan politik praktis. Seperti halnya Ummu Hani' yang dibenarkan sikapnya oleh nabi Muhammad saw ketika memberi jaminan 
ISLAMIC BANKING: Jurnal Pemikiran dan Pengembangan Perbankan Syariah, Volume 6 Nomor 1 Edisi Agustus 2020

keamanan kepada sebagian orang musyrik. Bahkan istri nabi Muhammd saw sendiri (Aisyah r.a) memimpin langsung peperangan melawan Ali Bin Abi Thalib yang ketika itu menduduki jabatan kepala negara.

Kedua, hak dan kewajiban perempuan dalam belajar. Belajar dalam Islam merupakan kewajiban semua umat manusia baik laki-laki maupun perempuan, bahkan menuntut ilmu termasuk ibadah. Karena dengan ilmu, seseorang akan mampu meraih kebahagiaan dunia dan akhirat. Dalam Q.S. az-zumar :9 disebutkan perbedaan yang jelas antara orang yang berilmu dan tidak berilmu. Hal ini membuktikan betapa pentingnya menuntut ilmu.

Al-qur'an memberikan pujian kepada ulul al-bab yang berdzikir dan memikirkan tentang kejadian langit dan bumi, dzikir dan pemikiran menyangkut hal tersebut akan mengantarkan manusia untuk mengetahui rahasia alam raya, yang kemudian mengantarkannya kepada penguasaan ilmu pengetahuan dan teknologi. Ulul al-bab tidak hanya terbatas pada kaum laki-laki, bunyi akhir rangkaian ayat tersebut membuktikannya Q.S Ali Imran : 195 “maka tuhan mereka mengabulkan permohonan mereka dengan berfirman: "sesungguhnya aku tidak menyia-nyiakan amal orang-orang yang beramal diantara kamu, baik laki-laki maupun perempuan" hal ini mengindikasikan bahwa perempuan dapat berpikir, mempelajari dan kemudian mengamalkan apa yang mereka hayati dari dzikrullah, serta apa yang mereka ketahui dari pengamatan alam raya. Pengetahuan menyangkut alam raya tentunya berkaitan dengan berbagai disiplin ilmu, sehingga dapat dipahami bahwa perempuan bebas untuk mempelajari apa saja, sesuai dengan keinginan dan kecenderungan masing-masing. (M. Quraish Shihab, 1998, p. 283)

Rasulullah saw tidak membatasi kewajiban belajar hanya kepada perempuanperempuan merdeka (yang memiliki status sosial tinggi), tetapi juga para budak belian dan mereka yang berstatus sosial rendah. Karena itu sejarah mencatat sekian banyak perempuan yang tadinya budak belian kemudian mencapai tingkat pendidikan yang sangat tinggi.(M.Quraish Shihab, 1998, p. 309)

Dari penjelasan diatas dapat disimpulkan, bahwa perempuan juga mempunyai hak dan kewajiban belajar. Sejarah membuktikan pada masa nabi dan setelahnya banyak 


\section{6 | Ahmad Mukri Aji, Harisah, Syarifah Gustiawan Mukri, HAK WIRAUSAHA PEREMPUAN..............}

wanita yang sangat menonjol pengetahuannya dalam berbagai bidang ilmu pengetahuan, sehingga menjadi rujukan sekian banyak tokoh lelaki. Misalnya istri nabi, Aisyah r.a adalah salah seorang yang mempunyai pengetahuan sangat dalam serta termasyhur sebagai seorang kritikus. Al-syaikhah Syuhra yang bergelar "fakhr al-nisa' “(kebanggaan perempuan) merupakan salah seorang guru Imam Syafi'i.

Sejalan dengan konsep yang ditawarkan oleh maqasid syariah adalah Allah swt selalu mempunyai maksud yang ingin dituju dari setiap perintah maupun larangannya, begitu juga kewajiban menuntut ilmu bagi perempuan. menuntut ilmu bisa dikatakan kebutuhan daruriyyat, dan juga hajiyyat. Dikatakan daruriyyat jika seorang yang Islam tapi tidak memahami cara maupun bacaan shalat, maka diwajibkan baginya untuk belajar ilmu tentang tata cara shalat. Dikatakan kebutuhan tahsiniyyat karena seorang perempuan yang tidak menuntut ilmu memang tidak akan merusak akalnya, namun akan mempersulit dalam mengembangkan ilmu pengetahuannya. Dengan ilmu pengetahuan seorang perempuan akan menghasilkan keterampilan dan menjadikan mutu kualitas pribadinya dapat meningkat. Yang tentunya akan berpengaruh pada kesejahteraan ekonomi yang menjadi salah satu faktor peningkatan kualitas hidup.

Dalam hadits nabi dikatakan bahwa perempuan adalah tiang bagi suatu negara bila baik perempuannya maka baik pula negaranya dan sebaliknya. Oleh karena itu, perempuan wajib belajar agar mendapat ilmu untuk bekal dalam menegakkan negaranya. Disamping itu perempuan merupakan ibu bagi anak-anaknya, sehingga diperlukan pengetahuan yang mumpuni untuk menjadi seorang ibu yang baik dan mampu mendidik anak-anaknya.

Ketiga, hak perempuan dalam pekerjaan. Dalam pandangan Islam, bekerja merupakan suatu kewajiban kemanusiaan yang tidak pernah terlepas dari kehidupan manusia sehari-hari. Perintah bekerja telah Allah wajibkan sejak nabi pertama yakni Adam a.s sampai nabi terakhir yakni Muhammad saw. Perintah ini berlaku kepada semua umat manusia tanpa membedakan pangkat, jabatan maupun jenis kelamin baik laki-laki maupun perempuan.

Bagi perempuan bekerja yang sudah menikah, Isnawati membaginya menjadi dua keadaan: bekerja karena keadaan tidak mendesak dan bekerja karena keadaan 
mendesak. Pertama, keadaan tidak mendesak artinya istri turut bekerja padahal keuangan keluarga dalam situasi stabil, suaminyapun ada dan mampu memenuhi kebutuhan rumah tangga. Kedua, keadaan mendesak artinya isteri menafkahi keluarganya dalam keadaan terdesak dikarenakan suaminya yang tidak ada, atau karena miskin.(Isnawati, 2018, p. 12)

Mengenai perempuan yang bekerja dalam keadaan tidak mendesak terdapat perbedaan pendapat, pendapat pertama mengatakan bahwa tidak seharusnya istri bekerja mencari nafkah. Karena bukan menjadi kewajibannya mencari nafkah atau memberi nafkah untuk anak-anaknya. Pendapat kedua mengatakan seorang ibu juga bertanggung jawab atas nafkah anak-anaknya, jika anak-anaknya sudah besar. Namun, jika anaknya masih kecil maka kewajiban nafkah sepenuhnya menjadi kewajiban suami. Sementara itu, bagi perempuan yang bekerja karena keadaan mendesak, terdapat perbedaan pendapat juga yaitu pendapat pertama mengatakan bahwa seorang ibu wajib menafkahi anak-anaknya jika ayahnya tidak ada atau suaminya dalam keadaan susah. Pendapat kedua mengatakan bahwa seorang ibu tidak wajib menafkahi anak-anaknya bagaimanapun keadaannya.(Isnawati, 2018, pp. 17-20)

Tidak jauh berbeda dengan apa yang dibedakan Isnawati, Hartini juga membedakan perempuan bekerja menjadi dua, yakni: mereka yang bekerja untuk penyaluran hobby, pengembangan bakat dan meningkatkan karir, sementara itu ada juga mereka yang bekerja untuk memenuhi kebutuhan hidup atau karena tekanan ekonomi, dengan kata lain untuk perbaikan sosial. Golongan pertama selalu menghubungkan lapangan pekerjaan dengan bakat mereka serta kesenangan, sedangkan perumusan material menjadi nomor dua. Sedangkan golongan yang kedua lebih banyak menghubungkan pekerjaan dengan pemenuhan kebutuhan material dengan penghasilan yang mereka terima.(Hartini, 1989, p. 9)

Menurut M. Quraish Shihab para wanita boleh bekerja dalam berbagai bidang, didalam maupun diluar rumah, baik secara mandiri atau bersama orang lain, dengan lembaga pemerintah maupun swasta, pekerjaan dilakukannya dalam suasana terhormat, sopan, serta selama mereka dapat memelihara agamanya, serta dapat pula menghindari 


\section{8 | Ahmad Mukri Aji, Harisah, Syarifah Gustiawan Mukri, HAK WIRAUSAHA PEREMPUAN.}

dampak-dampak negatif dari pekerjaan tersebut terhadap diri dan lingkungannya.(M. Quraish Shihab, 1998, p. 275)

Menurut Nuruddin ada beberapa norma yang harus diperhatikan oleh perempuan yang bekerja, yaitu:(Nuruddin, 2004, pp. 172-174) Norma pertama, menutup aurat. Menurut jumhur ulama batas aurat perempuan di depan laki-laki non mahram adalah seluruh tubuh, kecuali wajah dan telapak tangan.(Isnawati, 2020, pp. 15-16) Norma kedua, tidak berkhalwat antara laki-laki dan perempuan. Sebagaimana sabda nabi saw "bahwa tidaklah laki-laki dan perempuan berduaan kecuali syetan yang menjadi ketiganya". Norma ketiga, Tidak tabarruj (memamerkan perhiasan dan kecantikan).(Ibrahim Muhammad Al-Jamal, tt, p. 143) Sebagaimana firman Allah dalam surat al-ahzab: 33. Norma keempat, tidak melunakkan, memerdukan atau mendesahkan suara. Sebagaimana firman Allah dalam surat al-ahzab : 32. Norma kelima, Menjaga pandangan. Sebagaimana firman Allah dalam surat an-nur : 31.

Norma keenam Aman dari fitnah. Yang dimaksud aman dari fitnah disini adalah perempuan yang sejak menginjakkan kaki keluar rumah sampai kembali lagi ke rumah, mereka terjaga agamanya, kehormatannya serta kesucian dirinya. Norma ketujuh, pekerjaannya tidak mengorbankan kewajibannya di rumah. Artinya seorang perempuan yang bekerja tidak boleh mengabaikan kewajiban dan tanggung jawab dirumahnya, seperti sebelum bekerja harus memastikan suami dan anak-anaknya tetap terurus. Norma ke delapan, Mendapatkan izin dari orang tua dan suaminya. Norma kesembilan, pekerjaannya sesuai dengan tabiat sebagai seorang perempuan. Bentuk pekerjaan yang bisa dilakukan oleh kaum perempuan adalah bentuk pekerjaan yang tidak berbahaya, tidak berat dan tidak mengganggu keutuhan rumah tangga. Dan akan lebih baik jika kaum wanita bisa mengembangkan potensinya disekitar rumah atau profesi tidak menuntut perempuan untuk banyak keluar rumah. (Henny Syafriana Nasution, 2017, p. 35)

Konsep maqasid syariah merupakan konsep yang sangat penting dan fundamental yang menjadi bahasan dalam Islam. Hal ini telah diakui oleh para ulama dan menjadi acuan dasar dalam keberislaman. Adapun ruh dari konsep maqasid syariah adalah untuk mewujudkan kebaikan, sekaligus menghindarkan keburukan atau menarik manfaat dan 
menolak mudharat yang biasa kita kenal dengan dar'ul mafasid wa jalbul mashalih (درء (المفاسد وجلب المصالح . Oleh karena itu, sangat penting kiranya kita ketahui apa sebenarnya yang dimaksud dengan maqasid syariah.

Maqasid syariah terdiri dari dua kata yaitu maqasid (مقاصد) dan syariah (شريعة). Secara etimologi maqasid bermakna maksud, tujuan. Yang diambil dari kata قصديقصد.(Atabik Ali, 1996, p. 1454) Maqasid adalah bentuk plural dari kata al-maqsud (المقصود) dari akar kata al-qashd (القصد). Secara bahasa, sebagaimana yang dikutip oleh musolli dalam jurnalnya "maqasid syariah: kajian teoritis dan aplikatif pada isu-isu kontemporer" bahwa al-qashd mempunyai beberapa makna diantaranya:

Pertama, jalan yang lurus (istiqamah al-thariq). Makna tersebut mengacu pada surat al-Nahl: و وعلي الله قصد السبيل bahwa Allah berhak untuk menerangkan jalan yang lurus dan mengajak kepada makhluk untuk selalu berada pada jalan yang lurus. Kedua, tujuan yang paling utama (al-i'timad wa al-amm). Makna inilah yang sering kali digunakan dan dimaksud oleh ulama fiqh dan ulama ushul fiqh. Tujuan (al-maqasid) adalah acuan dalam setiap perbuatan mukallaf dan hukum berubah seiring dengan perubahan tujuan (al-maqasid). Ia adalah elemen yang terdalam yang menjadikan landasan dalam setiap perbuatan seseorang. Tujuan dan niat dalam hal ini tidak ada perbedaan yang mendasar.(Abd Al-Rahman Ibrahim Al-Kailani, 2000, p. 44)

Sedangkan kata "syariah" bermakna jalan menuju aliran air, atau jalan yang mesti dilalui, atau aliran sungai.(Ibnu Manzur, tt, p. 175) Kemudian ahli fiqh mengkaitkan makna tersebut dengan al-ahkam (hukum-hukum syariat) sehingga mengandung pengertian hukum-hukum yang ditetapkan Allah bagi hambanya. Maka disebutlah dengan ahkam syariah, karena hukum tersebut lurus, tidak bengkok, tidak sunyi dari hikmah dan tujuan.(Muhammad Ali Sayis, Tt, p. 5)

Adapun pengertian maqasid syariah secara terminologi ulama berbeda pendapat, diantaranya: Izzuddin Bin Abd Al-Salam mendefinisikan maqasid syariah adalah makna dan kebijaksanaan yang dipelihara oleh syari' pada semua penetapan hukum atau sebagian besarnya, sekalipun tidak dikhususkan untuk memeliharanya pada setiap jenis hukum dari hukum-hukum syariah, maka termasuk didalamnya setiap hal yang diberi sifat hukum dan tujuannya yang tidak terlepas syara' dalam memeliharanya. (Izzuddin 


\section{0 | Ahmad Mukri Aji, Harisah, Syarifah Gustiawan Mukri, HAK WIRAUSAHA PEREMPUAN..............}

Bin Abd Al-Salam, 1996, p. 10) lebih lanjut 'Izzuddin Bin Abd Salam menjelaskan bahwa semua maqasid bertujuan untuk memelihara aturan-aturan hukum yang ada dengan cara tahqiq al-mashalih (mewujudkan kemaslahatan) dan dar'u al-mafasid (menolak hal-hal yang merusak).

Ibn Ashur mendefinisikan maqasid syariah sebagai nilai atau hikmah yang menjadi perhatian syari' dalam seluruh kandungan syariat, baik yang bersifat terperinci atau global. Bisa jadi nilai-nilai itu memuat nilai universal syariah seperti al-wasathiyah (moderasi), al-tasamuh (toleran) dan al-shumul (holistik).(Ibn Ashur, 1979, p. 155) Sedangkan 'Allal Al-Fasi membuat definisi maqasid syariah sebagai tujuan-tujuan atau maksud-maksud disyariatkannya suatu hukum, serta rahasia-rahasia yang terkandung didalamnya yang ditetapkan oleh Allah swt (sebagai syari').('Allal Al-Fasi, Tt, p. 3) Sementara Wahbah Al-Zuhaili dalam kitabnya "ushul al-fiqh al-Islami" memberikan definisi maqasid syariah adalah tujuan-tujuan yang ingin dicapai oleh hukum Islam. (Wahbah Al-Zuhaili, 1986, p. 1049)

Dari beberapa definisi di atas dapat disimpulkan bahwa maqasid syariah merupakan maksud dan tujuan Allah dalam mensyariatkan suatu hukum, atau lebih tepatnya dikenal dengan tujuan hukum syara'. Tujuan hukum tersebut dapat difahami melalui penelusuran terhadap ayat-ayat al-qur'an dan sunnah Rasulullah saw. Penelusuran yang dilakukan ulama ushul fiqh menghasilkan kesimpulan bahwa tujuan asy-Syari' (pembuat hukum) dalam menetapkan hukum adalah untuk kemaslahatan manusia (al-maslahah).(Muhammad Said Ramdlan Al-Buti, 2000, p. 27) terkait hal ini Al-Syatibi menyatakan bahwa sesungguhnya Syari' dalam mensyariatkan hukumnya bertujuan untuk mewujudkan kemaslahatan hambanya baik di dunia maupun di akhirat secara bersamaan.(Abu Ishaq Al-Syatibi, 1997, p. 9)

Kemaslahatan yang akan diwujudkan menurut al-syatibi terbagi menjadi tiga tingkatan:(Abu Ishaq Al-Syatibi, 1997, p. 324) Tingkatan pertama, kemaslahatan dharuriyat (primer). Menurut Said Ramdhan Al-Buti kemaslahatan dharuriyat dimaknai sebagai kebutuhan yang tidak bisa dibiarkan atau ditunda keberadaannya dalam rangka menjaga keutuhan lima unsur pokok (al-umur al-khamsah), baik dengan menegakkan sendi-sendi yang utama, menetapkan kaidah-kaidahnya, menolak kesengsaraan yang 
akan terjadi. Penundaan atau menafikan tingkatan pertama ini akan menyebabkan terancamnya eksistensi kelima pokok unsur tersebut.(Muhammad Said Ramdlan AlButi, 2000, p. 110) Menurut Al-Syatibi, 5 unsur pokok itu adalah pemeliharaan agama (hifzh al-din), pemeliharaan keturunan (hifzhal-nasl),pemeliharaan jiwa (hifzh al-nafs), pemeliharaan akal (hifzh 'aql), dan pemeliharaan harta (hifzh al-mal).(Abu Ishaq AlSyatibi, 1997, p. 4)

Tingkatan kedua, kemaslahatan hajiyyat (sekunder) yaitu sesuatu yang diperlukan seseorang untuk memudahkannya menjalani hidup dan menghilangkan kesulitan dalam rangka memelihara lima unsur pokok tersebut. Artinya jika tingkat kemaslahatan sekunder ini tidak tercapai, maka manusia akan mengalami kesulitan memelihara agama, jiwa, akal, keturunan dan harta mereka.(Abd Rahman Dahlan, 2014, p. 310)

Tingkatan ketiga, kemaslahatan tahsiniyyat (tersier) adalah kebutuhan yang menunjang peningkatan martabat manusia dalam masyarakat dan dihadapan tuhannya, yakni dengan memperhatikan kesesuaian dengan kepatutannya.(Abd Rahman Dahlan, 2014, p. 111) Pada umumnya hal ini terdapat dalam pengertian akhlak mulia (akhlaqul karimah). Apabila kemaslahatan tersier tidak tercapai, manusia tidak sampai mengalami kesulitan memelihara kelima unsur pokok di atas, tetapi mereka dipandang menyalahi nilai-nilai kepatutan dan tidak mencapai taraf "hidup bermartabat".

Adapun contoh dari implementasi kemaslahatan 5 unsur pokok diatas yaitu: pertama, pemeliharaan agama/hifzh al-din; melaksanakan shalat lima waktu (dharuriyyat), pensyariatan shalat jamak dan qashar bagi orang yang sedang bepergian (hajiyyat), menghilangkan najis, bersuci, menutup aurat (tahsiniyyat). Kedua, pemeliharaan keturunan/ hifzh al-nasl; pensyariatan hukum perkawinan dan larangan melakukan zina (daruriyyat), ditetapkannya ketentuan menyebutkan mahar bagi suami pada saat akad nikah dan diberikan hak talak padanya (hajiyyat), disyariatkannya khitbah sebelum menikah dan walimah dalam perkawinan (tahsiniyyat). Ketiga, pemeliharaan jiwa/hifzh al-nafs; pensyariatan kewajiban memenuhi kebutuhan pokok berupa makanan untuk mempertahankan hidup (daruriyyat), dibolehkan berburu dan menikmati makanan yang halal dan bergizi (hajiyyat), disyariatkannya tatacara makan dan minum dengan cara duduk tidak dengan berdiri (tahsiniyyat). Keempat, 


\section{2 | Ahmad Mukri Aji, Harisah, Syarifah Gustiawan Mukri, HAK WIRAUSAHA PEREMPUAN.}

pemeliharaan akal / hifzh al-aql; pensyariatan haramnya mengkonsumsi minuman yang memabukkan atau minuman keras (daruriyyat), anjuran menuntut ilmu pengetahuan, artinya jika aktifitas menuntut ilmu tidak dilakukan, maka hal itu tidak akan merusak akal, namun akan mempersulit diri seseorang dalam mengembangkan ilmu pengetahuan (hajiyyat), menghindarkan diri dari menghayal atau mendengarkan sesuatu yang tidak berguna (tahsiniyyat). Kelima, pemeliharaan harta / hifzh al-mal; pensyariatan aturan kepemilikan harta dan larangan mengambil harta orang lain dengan cara yang diharamkan (daruriyyat), disyariatkannya jual beli dengan cara salam, jika cara salam ini tidak dilakukan maka tidak akan mengancam eksistensi harta, melainkan hanya akan mempersulit seseorang yang memerlukan modal (hajiyyat), menghindarkan diri dari penipuan (tahsiniyyat).

Dalam hal penetapan hukum, urutan kemaslahatan tersebut akan terlihat kepentingannya manakala bertentangan dalam kemaslahatan. Peringkat dharuriyyat menduduki tempat pertama, kemudian hajiyyat mendahului peringkat tahsiniyyat. Hal ini bisa disimpulkan bahwa peringkat ketiga melengkapi peringkat kedua dan peringkat pertama dilengkapi oleh peringkat kedua. Untuk mencapai kemaslahatan, dapat dicapai melalui dua cara yaitu: pertama, mewujudkan manfaat, kebaikan dan kesenangan untuk manusia. Hal ini biasa disebut dengan istilah jalb al-manafi'. Manfaat tersebut bisa dirasakan secara langsung saat itu juga atau tidak langsung pada waktu yang akan datang. Kedua, menghindari atau mencegah kerusakan dan keburukan. Hal ini biasa disebut dengan istilah “dar'u al-mafasid”.'(Ghofar Shidiq, 2009, p. 121)

Menurut Al-Juwaini yang poluler dengan nama Al-Imam Al-Haramain mengatakan bahwa seseorang tidak dapat dikatakan mampu menetapkan hukum dalam Islam, sebelum ia memahami dengan benar tujuan Allah mengeluarkan perintah dan larangannya. Oleh karena itu, sangat penting bagi seseorang untuk memahami maqasid syariah dalam menetapkan hukum Islam.(Abu Al-Ma'ali Abd Al-Malik Ibn Abdillah Ibn Yusuf Al-Juwaini, 1997, p. 101) Pernyataan al-juwaini tersebut menegaskan betapa pentingnya pengetahuan secara holistik tentang maqasid syariah.

Sedangkan Imam Al-Ghazali menegaskan bahwa dalam menetapkan hukum terlebih yang berkaitan dengan muamalah, haruslah memperhatikan nilai-nilai dimana ia 
dijadikan illat penetapan hukum, dan illat tersebut harus sesuai dengan maqasid syariah.(Mustafa Sa'id Al-Khin, Tt, pp. 552-554) Dalam kitab al-muwafaqat, Imam Asy-Syathibi secara tegas menjadikan pemahaman yang mendalam terhadap maqasid syariah sebagai syarat seorang mujtahid. Menurutnya, seseorang tidak mungkin mencapai derajat ijtihad jika tidak mengetahui maqasid syariah secara sempurna dan menjadikannya sebagai metode penggalian hukum.

Sementara Muhammad Az-Zuhaili mengemukakan urgensi maqasid syariah khususnya bagi seorang mujtahid, ahli hukum atau peneliti yaitu: Pertama, maqasid bisa dijadikan alat bantuan bagi mereka untuk mengetahui hukum syariah, baik yang bersifat universal maupun parsial dari dalil-dalil yang pokok dan cabang. Kedua, maqasid dapat membantu mereka dalam memahami teks-teks syariat dan mengimplementasikannya dengan benar, khususnya dalam tataran implementasi teks ke dalam realitas. Ketiga, maqasid dapat membantu mereka dalam menentukan makna yang dimaksud oleh teks secara tepat, khususnya ketika berhadapan dengan lafadz yang memiliki lebih dari satu makna. Keempat, ketika tidak mendapati problematika atau kasus kontemporer yang tidak ditemukan teks tentangnya, mujtahid atau ahli hukum Islam bisa merujuk ke maqasid syariah dengan menetapkan hukum melalui ijtihad, qiyas, istihsan, istishlah dan lain sebagainya sesuai dengan ruh, nilai-nilai agama, tujuan dan pokok-pokok syariat.Kelima, maqasid syariah dapat membantu seorang mujtahid, hakim dan ahli hukum Islam dalam melakukan tarjih dalam masalah hukum Islam ketika terjadi kontradiksi antara dalil yang bersifat universal atau parsial.(Muhammad Az-Zuhaili, tt, pp. 632-633)

Dari penjelasan diatas dapat disimpulkan bahwa pemahaman seorang mujtahid terhadap maqasid syariah dalam menetapkan suatu hukum sangatlah penting. Karena maqasid syariah akan membantu para mujtahid mengetahui tujuan hukum yang ditetapkan oleh Allah yang bersifat perintah maupun laranganNya.

\section{Implementasi Maqasid Syariah terhadap hak-hak wirausaha perempuan}

Salah satu cara mengatasi perekonomian yang buruk adalah melalui wirausaha. Berwirausaha berarti mampu menciptakan lapangan kerja bagi orang lain, dan mampu 


\section{4 | Ahmad Mukri Aji, Harisah, Syarifah Gustiawan Mukri, HAK WIRAUSAHA PEREMPUAN.}

mengembangkan kreatifitas diri untuk menghasilkan suatu produk. Kemauan dan kemampuan seseorang dalam menciptakan kegiatan usaha, mau berfikir kreatif dan inovatif dengan memanfaatkan sumber daya yang ada, serta berani mengambil risiko dan bertujuan untuk memberikan pelayanan yang baik dan memperoleh keuntungan yang besar merupakan ciri kewirausahaan.(Aqliyah, 2017, p. 28) Sedangkan kewirausahaan dalam pandangan Islam merupakan aspek kehidupan yang dikelompokkan dalam masalah mu'amalah, agar mampu menjaga dan menginvestasikan harta dengan cara yang baik, dengan menyeimbangkan kemaslahatan perseorangan maupun kemaslahatan umum.(Aqliyah, 2017, p. 39)

Segala bentuk transaksi yang diperbolehkan menurut syariah, berarti transaksi tersebut halal, seperti perniagaan atau bisnis yang sesuai dengan ajaran Islam. Wirausaha tidak hanya dilakukan oleh seorang laki-laki, akan tetapi, perempuan dalam pandangan Islam juga memiliki hak untuk melakukan wirausaha. Syariah memandang bahwa peran perempuan merupakan salah satu pendorong dalam kemajuan ekonomi suatu daerah, seperti kesuksesan Sayyidah Khadijah al-Kubra ra dalam dua dimensi, yaitu sebagai perempuan dalam kontek seorang isteri dan seorang ibu, serta sebagai sosialita yaitu sebagai pebisnis serta ummul mukminin.(Anggota Asosiasi Dewan Pengawas Syariah Wilayah IV Jawa Timur, Bali, Nusa Tenggara, n.d. Kumpulan Khotbah Bisnis dan Keuangan Syariah, kedua. ed., n.d., p. 82)

Wirausaha dalan Islam merupakan usaha yang dijalankan dengan nilai-nilai kebaikan. Seperti; kejujuran, komitmen pada kesepakatan, memuaskan konsumen dan lain sebagainya. Tanpa adanya nilai kebaikan, bisnis menjadi penyebab kemungkaran bagi yang menjalaninya. Bagi seorang muslim tujuan utama dalam berbisnis adalah keberkahan, dimana ciri utamanya adalah kemaslahatan.(Feddy Fabachrain, 2019, p. 45). Karena setiap aktivitas memiliki tujuan, begitu pula dengan tujuan syariah yang dikenal maqashid Syariah memiliki tujuan mencapai kemaslahatan dunia dan akhirat.(Nurul Fadhilah, 2020, p. 1). Begitu pula berwirausaha dalam pandangan maqashid syariah bertujuan untuk dunia dan akhirat, sehingga sebagai pelaku aktivitas usaha, seorang wirausaha syariah haruslah mendasari seluruh aktivitasnya kepada nilainilai yang dibawa oleh Islam.(Harisah, 2020, p. 14) 
Ada tujuh faktor yang memotivasi wanita dalam melakukan bisnis secara online antara lain faktor keluarga, faktor pengalaman dan fasilitas, faktor penghargaan dan peluang, faktor keinginan pribadi, faktor aktualisasi diri, faktor potensi diri, dan faktor pengangguran.(Safitri and Hatammimi, 2014, p. 7) faktor-faktor ini menjadi salah satu penentu perempuan berwirausaha, selain adanya faktor yang menjadi alasan perempuan berwirausaha, ada juga motivasi yang menjadikan perempuan berperan dalam mengembangkan wirausaha. Wirausaha wanita dalam mengelola usahanya telah mendasarkan pada dimensi inovasi, dimensi pengambilan resiko dan sikap proaktif dalam pengembangan usaha. Meskipun implementasi inovasi belum maksimal, akan tetapi pelaku usaha secara terus menerus berupaya untuk meningkatkan inovasi, baik dari sisi pengembangan produk, cara kerja maupun sistem pemasaran.(Wicaksono and Nuvriasari, 2012, p. 35). Seorang wirausahawan harus memiliki kemampuan antara lain; kemampuan merumuskan tujuan usaha, kemampuan memotivasi diri, kemampuan berinisiatif, kemampuan berinovasi, kemampuan membentuk material, sosial, dan intelektual, kemampuan mengatur waktu, kemampuan mental yang dilandasi agama, dan kemampuan membiasakan diri dalam mengambil hikmah dari pengalaman yang baik ataupun buruk. Dengan adanya kemampuan ini, maka akan meningkatkan skill dan memberikan motivasi dalam berusaha.(Munfaqiroh, 2016, p. 65)

Seperti yang dijelaskan sebelumnya bahwa perempuan yang bekerja bisa dikelompokkan menjadi dua: pertama, perempuan yang bekerja untuk penyaluran hobby, pengembangan bakat dan meningkatkan karir. kedua, perempuan yang bekerja untuk memenuhi kebutuhan hidup atau karena tekanan ekonomi. Golongan pertama selalu menghubungkan lapangan pekerjaan dengan bakat mereka serta kesenangan, sedangkan perumusan material menjadi nomor dua. Sedangkan golongan yang kedua lebih banyak menghubungkan pekerjaan dengan pemenuhan kebutuhan material dengan penghasilan yang mereka terima.

Menurut penulis jika dua keadaan tersebut dianalisis dengan maqasid syariah maka setidaknya dapat dikategorikan kepada dua macam, yakni: pertama, hifzh al-nafs (memelihara jiwa). Seorang perempuan yang bekerja karena dalam keadaan mendesak bisa dikatakan memelihara jiwanya yang daruriyyat, karena dengan bekerja seorang 


\section{6 | Ahmad Mukri Aji, Harisah, Syarifah Gustiawan Mukri, HAK WIRAUSAHA PEREMPUAN..............}

perempuan bisa menjaga kehidupan diri dan keluarganya dari kemiskinan. Apalagi kalau perempuan tersebut menjadi tulang punggung keluarga. Maka dalam hal ini, mau tidak mau perempuan tersebut harus bekerja demi menafkahi keluarganya. Sebagaimana sabda nabi "kalau ada seorang keluar dari rumahnya untuk bekerja guna membiayai anaknya yang masih kecil, maka ia telah berusaha fisabilillah. Jikalau ia bekerja untuk dirinya sendiri agar tidak sampai meminta-minta pada orang lain, itupun fisabilillah. Tetapi apabila ia bekerja untuk pamer atau untuk bermegah-megahan, maka itulah fisabili syaithan atau karena mengikuti jalan syaithan" (HR. thabrani)

Kedua, hifzh al-aql (memelihara akal). Seorang perempuan yang bekerja bukan karena dalam keadaan mendesak, bisa dikatakan memelihara akalnya yang hajiyyat. Karena bekerjanya bukan karena kebutuhan keluarganya, akan tetapi lebih kepada penyaluran bakat atau hobinya saja. Artinya jika bakatnya tersebut tidak disalurkan, maka perempuan tersebut akan merasa kesulitan dalam menjalani hidup. Namun hal ini, bisa masuk pada kategori daruriyyat jika pekerjaannya itu dibutuhkan oleh orang lain. Contoh seorang perempuan yang hobi menjahit, yang mana orang lain sangat membutuhkan pada jahitan perempuan tersebut.

\section{Simpulan}

Dalam pandangan maqashid syariah perempuan memiliki hak wirausaha, memberi arti bahwa perempuan memiliki hak untuk bekerja dengan beberapa syarat yaitu; dilakukan dengan cara sesuai syariah, dapat memelihara agamanya, sopan, dan dapat menghindari dampak-dampak negatif terhadap diri dan lingkungannya. Adapun wirausaha yang dikelola oleh perempuan dalam pandangan maqashid syariah masuk dalam kategori hifzh al-nafs (memelihara jiwa) dan hifzh al-aql (memelihara akal).

Jika seorang perempuan bekerja karena dalam keadaan mendesak, bisa dikatakan memelihara jiwanya yang daruriyyat, karena dengan bekerja seorang perempuan bisa menjaga kehidupan diri dan keluarganya dari kemiskinan. Apalagi kalau perempuan tersebut menjadi tulang punggung keluarga. Maka dalam hal ini, mau tidak mau perempuan tersebut harus bekerja demi menafkahi keluarganya, keadaan seperti itu masuk dalam kategori hifzh al-nafs (memelihara jiwa). Namun, jika perempuan yang bekerja bukan karena dalam keadaan mendesak, berarti mereka telah memelihara 
akalnya yang hajiyyat. Karena bekerjanya bukan karena kebutuhan keluarganya, akan tetapi lebih kepada penyaluran bakat atau hobinya saja. Artinya jika bakatnya tersebut tidak disalurkan, maka perempuan tersebut akan merasa kesulitan dalam menjalani hidup hifzh al-aql (memelihara akal).

\section{DAFTAR PUSTAKA}

Abd Al-Rahman Ibrahim Al-Kailani, 2000. Qawaid Al-Maqasid Inda Imam Al-Syatibi: 'Ardan Wa Dirasatan Wa Tahlilan. Damishq: Dar Al-Fikr.

Abd Rahman Dahlan, 2014. Ushul Fiqh. Jakarta: Amzah.

Abu Al-Ma'ali Abd Al-Malik Ibn Abdillah Ibn Yusuf Al-Juwaini, 1997. Al-Burhanfi Ushul Al-Fiqh, Jilid I. ed. Beirut: Dar Al-Kutub Al-Ilmiyah.

Abu Ishaq Al-Syatibi, 1997. Al-Muwafaqat. Beirut: Darul Ma’rifah.

'Allal Al-Fasi, Tt. Maqasid Al-Syariah Al-Islamiyah Wa Makarimiha. Persatuan Emirat Arab: Daar Al-Baidla'.

Anggota Asosiasi Dewan Pengawas Syariah Wilayah IV Jawa Timur, Bali, Nusa Tenggara, n.d. Kumpulan Khotbah Bisnis dan Keuangan Syariah, kedua. ed., kedua. ed, n.d. . Otoritas Jasa Keuangan: Ragional 4 Jawa Timur.

Aqliyah, M., 2017. Strategi meningkatkan kemampuan santri di bidang kewirausahaan dalam menghadapi Masyarakat Ekonomi Asean (MEA) (studi kasus di Ponpes al-Mawaddah Honggosoco Kudus) (PhD Thesis). UIN Walisongo.

Aravik, H., Sulastyawati, D., \& Yunus, N. R. 2020. Leadership Concept At Sharia Bank; A Theoretical Study. Islamic Banking: Jurnal Pemikiran Dan Pengembangan Perbankan Syariah, 5(2), 21-32.

Atabik Ali, 1996. Kamus Kontemporer. Yogyakarta: Multi Gaya Grafika.

Feddy Fabachrain, 2019. Kumpulan Kultum Ekonomi Syariah. Komite Nasional Keuangan Syariah, Indonesia: Gedung Permata Kuningan.

Ghofar Shidiq, 2009. Teori Maqasid Al-Syariah Dalam Hukum Islam. Sultan Agung XLIV, No. 130.

Harisah, 2020. Kumpulan Kultum Ekonomi Syariah "Membumikan Ekonomi dan Keuangan Syariah untuk Kemajuan Negeri," kedua. ed. Komite Nasional Keuangan Syariah, Jakarta.

Hartini, 1989. Peran Wanita Dalam Rangka Meningkatkan Kesejahteraan Sosial Keluarga Melalui Usaha Ekonomi Produktif. Yogyakarta: Departemen Sosial RI. 


\section{8 | Ahmad Mukri Aji, Harisah, Syarifah Gustiawan Mukri, HAK WIRAUSAHA PEREMPUAN.}

Henny Syafriana Nasution, 2017. Wanita Bekerja Dalam Pandangan Islam. Almufida II, No. 02.

Ibn Ashur, 1979. Maqasid Al-Syariah Al-Islamiyah. Tunisia: Al-Maktabah AlTunisiyah.

Ibnu Manzur, tt. Lisan Al-'Arab, Juz VIII. ed. Beirut: Dar Shadir.

Ibrahim Muhammad Al-Jamal, tt. Fiqhul Mar'ah Al-Muslimah, Terj.Anshori Umar Sitanggal. Semarang: Asy-Syifa'.

Isnawati, 2020. Aurat Wanita Muslimah. Jakarta: Rumah Fiqh Publishing.

Isnawati, 2018. Isteri Bekerja Mencari Nafkah. Jakarta: Rumah Fiqh Publising.

Izzuddin Bin Abd Al-Salam, 1996. Al-Qawaid Al-Shugra. Beirut: Dar Al-Fikr AlMu'ashirah.

M. Quraish Shihab, 1998. Membumikan Al-Qur'an. Bandung: Mizan.

M.Quraish Shihab, 1998. Wawasan Al-Qur'an: Tafsir Maudhu' Atas Persoalan Umat. Bandung Mizan.

Muhammad Ali Sayis, Tt. Tarikh Al-Fiqh Al-Islamy. Mesir: Maktabah Ali Shobih.

Muhammad Az-Zuhaili, tt. Mausu'ah Qadhaya Islamiyyah Mu'ashirah, Bagian Maqasid Alsyariah, juz 5. ed. Damaskus: Dar Al-Maktabi.

Muhammad Said Ramdlan Al-Buti, 2000. Dhawabit Al-Maslahah Fi A-Syaria AlIslamiyyah. Beirut: Muassisah Al-Risalah.

Munfaqiroh, S., 2016. Faktor yang mempengaruhi wirausaha wanita miskin untuk mencapai keberhasilan usaha. J. JIBEKA 10, 57-65.

Mustafa Sa'id Al-Khin, Tt. Athar Al-Ikhtilaf Fi Al-Qawaid Al-Ushuliyyah Fi Ikhtilaf Al-Fuqaha. (Beirut: Dar Al-Fikr.

Nuruddin, 2004. Ada Apa Dengan Wanita. Yogyakarta: Taslima Prisma Media.

Nurul Fadhilah, 2020. Kumpulan Kultum Ekonomi Syariah "Membumikan Ekonomi dan Keuangan Syariah untuk Kemajuan Negeri,” kedua. ed. Komite Nasional Keuangan Syariah, Jakarta.

Safitri, T.Y., Hatammimi, J., 2014. Analisis Faktor-Faktor yang Memotivasi Wanita Berwirausaha Melalui Bisnis Online (Studi pada Mahasiswi Sekolah Bisnis di Bandung). EProceedings Manag. 1.

Wahbah Al-Zuhaili, 1986. Ilmu Ushul Al-Fiqh. Beirut: Daar Al-Fikr.

Wicaksono, G., Nuvriasari, A., 2012. Meningkatkan kinerja umkm industri kreatif melalui pengembangan kewirausahaan dan orientasi pasar: Kajian pada peran serta wirausaha wanita di kecamatan moyudan, kabupaten sleman, propinsi diy. J. SosioHumaniora 3. 